\title{
Bylaws of the Women's Studies Section
}

\section{ACRL's newest section.}

E ditor's note: These bylaws were approved by the ACRL Board of Directors at their meeting on January 20, 1987.

\section{Article I. Name}

Section 1. The name of this organization shall be the Women's Studies Section of the Association of College and Research Libraries, a division of the American Library Association.

\section{Article II. Purpose}

Section 1. This section shall represent librarians and others who specialize or are otherwise professionally involved in the cross-disciplinary field of Women's Studies. It may cooperate with other professional groups in regard to those aspects of library and information services that require special knowledge of Women's Studies.

Section 2. The Women's Studies Section has specific responsibilities:

a) To discuss, promote, and support Women's Studies collections and services in academic and research libraries;

b) To foster the development of bibliographic instruction, liaison with faculty, and database searching in this cross-disciplinary field;

c) To encourage cooperative collection development of and access to Women's Studies materials;

d) To foster cooperation among Women's Studies librarians, scholars, students, and publishers;

e) To work with other ALA groups to promote library and information services to women.

\section{Article III. Membership}

Section 1. Any member of the Association of College and Research Libraries may elect membership in the Women's Studies Section. Every member has the right to vote and is eligible to hold office.

\section{Article IV. Officers}

Section 1. Officers. Elective officers of this Section shall be a chair, a vice-chair/chair-elect, the immediate past chair, a recorder, and a memberat-large, who shall be a representative to the Executive Committee who acts on behalf of the membership.

Section 2. Terms. All officers shall serve for a term of one year which ends at the adjournment of the annual meeting.

Section 3. Vacancies. In case of a vacancy in the office of chair, the vice-chair/chair-elect shall succeed to the office of chair and shall continue in that office until the expiration of the term for which $s /$ he was originally elected to serve as chair.

A vacancy in the office of vice-chair/chair-elect shall be filled by election. In case of a vacancy in the offices of recorder or member-at-large, a replacement will be appointed by the chair.

In case of vacancies in both the offices of chair and vice-chair/chair-elect, the member-at-large shall act as chair until the next election.

\section{Article V. Meetings}

Section 1. Annual Meetings. The Section shall hold an annual business meeting at the time and place of the Annual Conference of the American Library Association.

Section 2. Quorum. Members of the Section present at an annual meeting shall constitute a quorum.

\section{Article VI. Executive Committee}

Section 1. Composition. The Executive Committee shall consist of the officers and, ex-officio without vote, the chairs of standing committees.

Section 2. Powers and Duties. The Executive Committee shall conduct the business of the Sec- 
tion during the period between annual Section meetings.

Section 3. Meetings. Regular meetings of the Executive Committee shall be held at the time and place of the Annual and Midwinter Conferences of the American Library Association. Special me tings may be called at the discretion of the chair

Section 4. Quorum. A majority of members shall constitute a quorum at any meeting of the Executive Committee.

\section{Article VII. Committees}

Section 1. Standing Committees. Standing committees to consider matters of concern to the Section that require continuity of attention may be authorized by the Section at the annual Section meeting. The size, name, purpose, membership, terms of membership, and chair of a standing committee shall be specified at the time of its authorization. The vice-chair/chair-elect shall appoint committee members to fill vacancies due to occur during her/his term as chair. Unexpected vacancies on a committee shall be filled by a special appointment made by the chair of the committee with approval of the chair of the Section. A standing committee may be discontinued by a majority vote of the members present and voting at an annual Section meeting.

Section 2. Special Committees. Special or ad hoc committees may be authorized as needed by the Executive Committee of the Section.

\section{Article VIII. Nominations and Elections}

Section 1. Nominations. The vice-chair/chairelect of the Section, with the approval of the chair, shall appoint a Nominating Committee of at least three personal members of the Section. This committee shall choose a slate of at least two candidates for each office of the Section. Additional nominations may be made by petitions signed by no fewer than five Section members. All nominees must be members in good standing of the Section and must consent to candidacy in writing. All nominations shall be filed with both the Executive Director of ACRL and the recorder of the Section within the deadlines prescribed by ACRL.

Involvement in or commitment to the acquisition, organization, or use of Women's Studies information sources should be considered in selecting nominees for office.

Section 2. Elections. Elections shall be conducted by mail ballot in accordance with the procedures and deadlines established by the American Library Association. For each office, the candidate receiving a plurality of votes cast shall be elected, and the results reported to the Executive Director of ACRL. In case of a tie vote, the successful candidate shall be determined by lot.

\section{Article IX. Amendments}

Section 1. Proposals. Amendments to these Bylaws may be proposed in writing to the membership of the Section by the Executive Committee, a committee appointed specifically for the purpose, or by any five members of the Section. Proposals shall be filed with the recorder at least three months before final consideration.

Section 2. Notification. The recorder will arrange publication of the proposed amendments not less than one month before final consideration.

Section 3. Voting. A plurality vote of the members present and voting at an annual meeting or casting ballots in a mail vote shall carry a proposed amendment.

\section{Article X. General Provisions}

Section 1. Wherever these Bylaws make no specific provisions, the organization of and procedures in the Section shall correspond to those set forth in the ACRL Constitution and Bylaws.

Section 2. These Bylaws and amendments thereto shall take effect upon approval.

\section{Revised Section Newsletter Policy}

The following policy regarding ACRL section newsletters was passed by the ACRL Board of Directors on January 20, 1987, pending comment from the sections. This rescinds the previous policy approved in January 1985.

1. The ownership statement for section newsletters will be designed such that it will include the name of the section, name of the division (ACRL), ALA, and other essential elements as described in "ALA Periodicals: Essential Elements," an ALA Publications Committee document of July 10, 1982.

2. Each section publishing a newsletter will pro- vide a written report to the Publications Committee at Annual Conference.

3. Each section may expect to receive funding for either two newsletters a year of 8 pages each, or one newsletter a year of up to 16 pages.

4. Section editors may submit camera-ready copy to ACRL Headquarters, according to specifications prepared by the ACRL staff. Headquarters staff will then have the responsibility for getting the newsletters printed and mailed (first class) within two weeks of receipt of the camera-ready copy.

5. Section editors have the option of using local 
institutions or vendors for printing and mailing. The section newsletter editor's annual report will contain a financial section describing all local expenditures. Under no circumstances will ACRL provide funding for production expenses incurred by an outside institution or vendor that exceed the level budgeted for in-house production or coordination.

6. Each section shall be provided, for each issue of its newsletter, a number of copies not to exceed $10 \%$ of the number of members in the section, at no charge, for the section to distribute at its own cost and discretion.

7. Sections may establish a policy on subscrip- tions to their newsletters. Paid subscription orders only will be taken by the ACRL staff.

8. If a section believes that the content of its newsletter requires that the newsletter be more extensive than its allotted 16 pages as outlined in 3 above, the section may request funding for additional pages or issues. This special funding must be approved by the ACRL Publications Committee and must be submitted as part of the section's normal budget request to the ACRL Budget and Finance Committee. Requests for such special funding must specify the number of additional pages planned and justify the need for them.

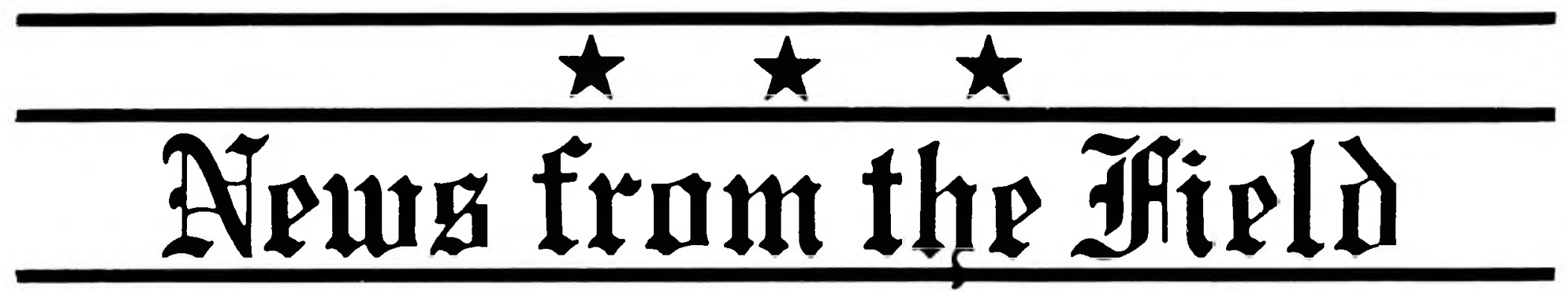

\section{Acquisitions}

- The Library of Congress's Music Division, Washington, D.C., has acquired a major collection of nearly 400 music manuscripts and papers of American bandmaster and composer John Philip Sousa (1854-1932), the gift of Sousa's grandsons. The materials have been on deposit in the Library for many years, and have been indexed and microfilmed. Titles in the collection include some of Sousa's best-known compositions: Corcoran $\mathrm{Ca}$ dets; The High School Cadets; King Cotton; The Liberty Bell; Manhattan Beach; Nobles of the Mystic Shrine; Our Flirtations; and Solid Men to the Front. Also included are the manuscripts of $\mathrm{El}$ Capitan and The Bride Elect, two works representing the composer's contribution to operetta; Sheridan's Ride; and the suites, The Last Days of Pompeii and Dwellers of the Western World. The collection also contains sketchbooks and literary items including Sousa's autobiography and a semiautobiographical novel.

- New York University's Tamiment Institute Library, New York City, has acquired the archival materials of Greenwich House, an important center of social welfare and betterment of the Greenwich Village community since the early years of the century. The material includes photographs, minutes from Board of Directors meetings, files and correspondence. Incorporated in 1901 as the Cooperative Social Settlement Society of the City of New York by Mary Kingsbury Simkovitch with Felix Adler, R. Fulton Cutting, Eugene A. Philbin, Henry C. Potter, Jacob Riis and Carl Schurz, Greenwich House was originally located on Jones Street in one of the most crowded areas of the lower west side. It played a vital role in the im- provement of the neighborhood, working for better sanitation, paved streets, child labor laws, increased recreational and cultural opportunities for adults and children, slum clearance and improved housing, and a more responsive city government. Following the move in 1917 to its present location on Barrow Street, Greenwich House established the first child care facilities for working mothers. Through its research studies of living conditions in the Village, many conducted by John Dewey's Social Research Committee, it made contributions to social action, examining wage levels and the standard of living, old age and poverty, and housing problems of longshoremen and dock workers. Now a historic landmark, Greenwich House continues to sponsor special programs and a range of community activities.

-Rutgers University's Art Library, New Brunswick, New Jersey, recently acquired 850 volumes on art history from art historian, author and teacher Howard Hibbard, of Columbia University. The collection consists primarily of works dealing with the Italian Renaissance and Baroque Art, with some material on the Northern Renaissance. Hibbard, a Fellow of the American Council of Learned Societies, is the author of books on Bernini, Caravaggio, Michelangelo, and Carlo Moderno. He is a former director of the Society of Architectural Historians and from 1974-78 was chief editor of Art Bulletin.

- Stanford University's Hoover Institution Archives, California, has acquired the papers of Sir Karl Popper, internationally acclaimed philosopher of natural and social science. Born in Vienna in 1902, Popper is the author of The Open Society and Its Enemies (1945) and The Poverty of Historicism, and is regarded as one of the greatest living 